\title{
The Analysis on Chinese Foreign Exchange Reserves Proper Scale and Measurement
}

\author{
Sun Yexia \\ School of Marxism \\ Northeast Normal University \\ People Street No.5268, Nanguan District \\ Changchun, Jilin Province, China \\ sunyexia@126.com
}

\author{
Han Bing \\ School of Taxation \\ Jilin University of Finance and Economics \\ Jingyue Street No. 3699 \\ Changchun, Jilin Province, China
}

\begin{abstract}
It is an issue how to calculate the proper scale of foreign exchange reserves. The existing researches about this utilize many models and methods but there is a lack of integrity and theory. This paper will try to calculate the proper scale of foreign exchange reserves from the perspective of demand using money means of purchase, means of payment and wealth functions as the independent variables. We establish a formula appropriate to China's true situation and then calculate the appropriate scale of Chinese foreign exchange reserves from 2007 to 2015. The results show that excess foreign exchange reserves exist in China and the excess foreign exchange reserve shows an upward trend year by year but in 2014 there is a turning point.
\end{abstract}

Keywords-Foreig Exchange Reserves; Monetary International Function; Foreign Exchange Reserves; Proper Scale

\section{INTRODUCTION}

Since 2006 when Chinese foreign exchange reserves exceeded Japanese reserves the reserves entered a rising phases. According to the financial statistics released by the People's Bank of China, by the end of June 2014 the balance of foreign exchange reserves approached the level of \$ 4 trillion and then down to $\$ 3.84$ trillion at the end of the year. By the end of 2015, although the foreign exchange reserves decreased it was still as high as 3.33 trillion US dollars. The increase of foreign exchange reserve is the embodiment of our country's economic strength which improves the ability of foreign payment, solvency, international credit and international financing. However, huge foreign exchange reserves brought many problems to Chinese foreign exchange reserve management. This paper will make a meaningful attempt to measure the proper scale of Chinese foreign exchange reserves.

\section{The CurRency EXCHANGe MEANS Demand FOR Foreign EXCHANGE RESERVES}

The international commodity trading such as goods and services generated the requirement of foreign exchange reserves. In 1947, the United States well-known economist, Professor Triffin proposed that the ratio of reserves and imports could be used as a measure of the adequacy of foreign exchange reserves standards. In his book The Crises of Gold and the Dollar published in 1960, he studied and estimated the

This paper is the medium-term outcomes for National Social Science Fund Youth Project "Marx’s Exchange Rate Theory and China's Financial Security” (14CJL002). reserves of 12 major trading nations. It is concluded that the goal of most countries is to keep their foreign exchange reserves at over $40 \%$ of their trade imports for most of the year if excluding some short-term or random factors. If the ratio is less than $30 \%$ or $33 \%$ it is the responsibility of the State to adopt adjustment measures. $20 \%$ of the total reserve level is considered to be an absolute minimum. The best ratio of the foreign exchange reserves and imports accounts for about $25 \%$, which means that a country's foreign exchange reserves should meet the needs of 3 months imports. The role of trade in services in economic development is growing and demand more foreign exchange reserves it should also be included as one of the factors into the foreign exchange reserve needs[1]. In this paper, I will calculate the demand on service trades as the proportion of $100 \%$ of the total amounts.

\section{THE CURRENCY PAYMENT DEMAND FOR FOREIGN EXCHANGE RESERVES}

As an international currency, American dollar is paid reserves by the countries besides the United States can balance trade gap of these countries. But for the trade balance between the United States and other countries, American dollar does not have the function of balancing it. When the United States produces absolute trade imbalance for other countries, the output of the dollar can't balance the international trade deficit, and the transfer of the dollar is also unable to offset the international trade imbalance. The balance of international trade will be wider if the economic policy is not be adjusted, and the United States has developed into the world's largest trade deficit country. As a country outside the United States, holding foreign exchange reserves can offset the trade deficit and maintain a country's necessary, normal import capacity. When a country has sporadic international trade deficit caused by political, economic and natural factors, it can be remedied by its foreign exchange reserves. Foreign exchange reserves can also play a mitigating role if a country's international balance of payments needs to be resolved by adjusting the industrial structure and improving the investment environment, to a certain extent, it can alleviate the domestic economic impact on account of the adjustment. Foreign exchange reserves' function of compensating for trade imbalance is from the international monetary means of payment of foreign exchange reserves, mainly closely related with trade, and reflected in the outflow of funds from the country each year on 
the balance of payments sheets for the foreign direct investment enterprises and foreign investment enterprises[2].

\section{THE WORLD'S WEALTH DEMAND FOR FOREIGN EXCHANGE RESERVES}

At present, dollar is an international currency, foreign exchange reserve can still serve as the wealth of each country to pay for external debt or borrowing, and foreign exchange reserve becomes a powerful means of maintaining exchange rate stability. It can guarantee foreign exchange demand of external debt principal and interest payments. This part of medium of payment is mainly reflected in the outstanding external debt. As a rule of thumb, when the foreign exchange reserve / foreign debt ratio is greater than or equal to $30 \%$, a country's external solvency is relatively sufficient. The shortterm foreign debt measurable indicator is the ratio of foreign exchange reserve / short-term foreign debt, which reflects the ability of a country to repay its short-term foreign debt. Generally, the amount of foreign exchange reserve is sufficient when the ratio is no less than $100 \%$.

Adequate foreign exchange reserve can serve as a strong means of maintaining exchange rate stability for a government. As a fixed exchange rate regime, in order to maintain a stable exchange rate, a country's monetary authority must hold a certain amount of foreign exchange, and stabilizes the national currency exchange rate with the exchange rate level of adapting to the national economic level. When the domestic currency is depreciated in the foreign exchange market, dollar exchange will be thrown to purchase domestic currency to decrease the amount of domestic currency in the foreign exchange market, and thus plays a role in promoting the domestic currency value. When the domestic currency is appreciated in the foreign exchange market, domestic currency will be thrown to purchase American dollar to increase amount of domestic currency in the foreign exchange market, and thus plays a role in reducing the domestic currency value. In addition, this monetary intervention will also affect the psychology of market participants, and takes a positive effect. But in the face of huge international capital speculative storm, the foreign exchange reserve must be enough, and it may come in stabilizing the currency [3]. Otherwise, the foreign exchange reserve into the foreign exchange market has not worked, and then it will result in the loss of reserves and the depreciation of exchange rate.

\section{THE CALCULATION OF CHINA'S FOREIGN EXCHANGE RESERVES’ APPROPRIATE SCALE}

Foreign exchange reserves can play an active part in balancing international payments, improving the ability to pay abroad, stabilizing the exchange rate of the domestic currency and coping with the impact of the international financial crisis. If the number of foreign exchange reserves is too small, it will affect the function of international currency, and will decline a country's international purchasing power and payment capacity, or even currency fluctuation. But too much foreign exchange reserves will produce a lot of foreign exchange risk. So it is necessary to estimate the size of foreign exchange reserves. In the international monetary functions, the measure of value function can also be the same with the domestic currency, is the currency of concept, without the realistic currency. The general means of exchange of international money works with international means of purchase and international payment means. To facilitate the measurement of the size of the foreign exchange reserve, we can measure from the general means of payment of foreign exchange reserve and absolute social function serving as wealth. In particular, the demand for money in the international means of payment is manifested in the trade of goods and trade in services in the general means of payment; the demand for money in the means of payment is manifested in the direct investment and the outflow of foreign capital in China; the absolute social function serving as wealth is mainly in the repayment of foreign debt and regulation of funds of foreign exchange market. These factors above constitute the basic content of the demand for foreign exchange reserves [4]. Therefore, we can adopt the following methods to define the appropriate scale Q of foreign exchange reserve:

$$
\mathrm{Q}=(\mathrm{CT}+\mathrm{ST})+(\mathrm{FI}+\mathrm{RI})+(\mathrm{FD}+\mathrm{MD})
$$

Among them, $(\mathrm{CT}+\mathrm{ST})$ is the demand of the function of international purchase means for foreign exchange, CT is the demand of commodity trade for foreign exchange reserve, ST is the demand of trade in service for foreign exchange reserve, $(\mathrm{FI}+\mathrm{RI})$ is the demand of executing the function of international payment means for foreign exchange, FI is the demand of China's foreign direct investment for foreign exchange, RI is the outflow of profit of foreign investment in China each year, (FD + MD) is the social function of the implementation of wealth, FD is the demand of repaying the principal and interest of foreign debt, and MD is the fund demand of stable exchange.

First, Maintaining the normal import demand includes maintaining the foreign exchange needs of imported goods trade and service trade. According to Triffin's foreign exchange reserve and import ratio theory, a country's foreign exchange reserve should be able to meet the 3-6 months of import payment needs. The cost of excessive holding foreign exchange reserve is quite high, which is not necessary. Therefore, this paper assumes that this part of the foreign exchange demand is $50 \%$, which meets the six months of import payment requirements. By calculating, China's goods gross imports amount was 1.7353 trillion US dollars in 2014, there was a need of 867.65 billion US dollars paying six months of imports needs, and the amount of imports was 185.91 billion US dollars in 2015, then there was a need of 929.55 billion US dollars paying six months of imports needs.

Demand for service trade (ST): with the continuous improvement of globalization degree, the consistent development of communication and science and technology, the role of service trade in economic development is becoming stronger and stronger. China's demand for foreign exchange in service trade is ever-increasing. This demand is closely related to the rapid development of our economy and the continuous increase of national income. Therefore, service trade should be included as one of the factors into the demand for foreign exchange reserve. China's service trade expenditure was \$ 281.2 billion and foreign payment was $\$ 281.2$ billion in 
2014. In 2015, the scale of China's service trade expenditure was \$ 330.5 billion.

Second, the demand for foreign direct investment. With the constant enhancement of China's economic strength, domestic demand for foreign investment is increasing, the continuous relaxation of foreign exchange controls also allows more and more individuals and businesses to seek opportunities and developments into foreign countries [5]. In 2014, China's foreign direct investment increased rapidly, reaching 88.3 billion US dollars, and the payment was 88.3 billion US dollars. China's foreign direct investment was 109.6 billion US dollars in 2015, and the foreign exchange demand was 109.6 billion US dollars. Foreign capital outflow of funds produces demand for foreign exchange. Most of the articles indicate the outflow of foreign-funded enterprises by the demand for investment profits. According to international practice, it is pointed out that the proportion of remittance profits of foreign direct investment enterprises are generally between $8 \%$ and $12 \%$. According to the World Bank study, foreign-invested enterprises in China average return on investment of $15 \%$. While the foreign-invested enterprises in the golden period have been into the profit-making period, and profits exports will increase. The outflow of foreign capital in 2014 was \$ 31.1 billion, compared to \$ 53.2 billion in 2015 .

Third, the demand for repayment of the principal and interest of foreign debt (FD). In today's condition that global capital flows rapidly, a country's foreign exchange reserve should focus on to consider the short-term foreign debt to meet a year and part of the medium-term and long-term external debt payments. According to experience, a country's external solvency is more adequate when its foreign exchange reserve / foreign debt ratio is greater than or equal to $30 \%$. The measure indicator of short-term foreign debt is the ratio of foreign exchange reserve / short-term foreign debt, which reflects the ability of a country to repay its short-term foreign debt. Generally, the ratio of foreign exchange reserves is sufficient when the ratio is more than $100 \%$. Therefore, for prudent purposes, we set the ratio of foreign exchange reserve / short-term foreign debt to $100 \%$ and the ratio of foreign exchange reserve / long-term foreign debt to $30 \%$. At the end of 2014, China's short-term foreign debt balance was 540.93 billion US dollars, and long-term foreign debt balance was 736.99 billion US dollars. Short-term foreign debt was calculated as $100 \%$ of the annual repayment, then China's short-term, long-term foreign debt to foreign exchange reserve was 762.027 billion US dollars. At the end of 2015, China's short-term external debt balance was 676.63 billion US dollars, medium and long-term foreign debt balance was 863.17 billion US dollars, while the foreign exchange reserve was 935.581 billion US dollars.

Foreign exchange market funds are regulated, according to international experience, the amount of foreign exchange stabilization funds held by the government to intervene in the foreign exchange market should be equivalent to one month's imports amount when a country is fully convertible under the current account and capital account. Financial Research Center Research Group of Beijing Normal University believes that the lower limit of intervening foreign exchange market and maintaining foreign exchange reserve of exchange rate stability is 1 month of imports amount, the maximum limit is 1.5 months of imports amount. This paper defines the China's foreign exchange reserve level which meets the demand for foreign exchange market capitalization as 1.5 months of equivalent amount of foreign exchange when analyzing the appropriate scale of foreign exchange. The average monthly imports volume in 2014 was 201.65 billion US dollars, and then the fund amount of regulating foreign exchange market was 302.475 billion US dollars. The average monthly imports in 2015 amounted to 248.1 billion US dollars, and then the fund amount of regulating foreign exchange market was 372.15 billion US dollars.

In summary, we can basically calculate the appropriate scale of China's foreign exchange reserve, China's moderate foreign exchange reserve in 2004 should be as follows:

$\mathrm{Q} 12=(8676.5+2812)+(883+31)+(7620.27+3024.75)$

$=23327.52$ billion dollars

China's moderate foreign exchange reserve in 2015 was:

$\mathrm{Q} 13=(9295.5+3305)+(1096+532)+(9355.81+3721.5)$

$=27305.81$ billion dollars

From the actual view of China's economic operation and economic development, China's foreign exchange reserve balance was 3.84 trillion US dollars in 2014. China's foreign exchange reserve amounted to 3.33 trillion US dollars in 2015, beyond a moderate scale. I can get the table as below after analyzing the existing data. The gap between Chinese foreign exchange reserves and the proper scales gets bigger from 2007 to 2015 . 
TABle I. The Proper Scale of Chinese Proper Foreign EXCHANGe Reserves From 2007 to 2015

\begin{tabular}{|c|c|c|c|c|c|c|c|c|c|}
\hline Year & 2007 & 2008 & 2009 & 2010 & 2011 & 2012 & 2013 & 2014 & 2015 \\
\hline Goods Imports & 6283 & 7519 & 9041 & 10741 & 9543 & 13272 & 16603 & 17353 & 18591 \\
\hline Goods Imports of 6 months & 3141 & 3760 & 4521 & 5370 & 4771 & 6636 & 8301 & 8676 & 9295 \\
\hline Service Imports & 840 & 1008 & 1301 & 1589 & 1589 & 1933 & 2477 & 2812 & 3305 \\
\hline Direct Investment & 143 & 247 & 191 & 589 & 481 & 656 & 658 & 883 & 1096 \\
\hline Outflows of foreign companies & 65 & 85 & 112 & 131 & 318 & 217 & 341 & 311 & 532 \\
\hline The balance of short-term foreign debts & 1716 & 1992 & 2357 & 2263 & 2593 & 3757 & 5009 & 5409 & 6766 \\
\hline The balance of long-term foreign debts & 1249 & 1394 & 1535 & 1639 & 1694 & 1732 & 1941 & 1961 & 1865 \\
\hline The balance of long-term foreign debts $* 30 \%$ & 375 & 418 & 461 & 492 & 508 & 520 & 582 & 588 & 560 \\
\hline Funds adjusting the foreign exchange market & 785 & 940 & 1130 & 1343 & 1193 & 1659 & 2075 & 2169 & 2324 \\
\hline Proper Scale & 7066 & 8450 & 10072 & 11777 & 11453 & 15378 & 19444 & 20849 & 23879 \\
\hline
\end{tabular}

The specific data is shown in the table below:

TABLE II. THE CHINESE FOREIGN EXCHANGE RESERVES \& PROPER SCALES FROM 2007 TO 2015

Unit: Billion Dollars

\begin{tabular}{|c|c|c|c|c|c|c|c|c|c|}
\hline Year & $\mathbf{2 0 0 7}$ & $\mathbf{2 0 0 8}$ & $\mathbf{2 0 0 9}$ & $\mathbf{2 0 1 0}$ & $\mathbf{2 0 1 1}$ & $\mathbf{2 0 1 2}$ & $\mathbf{2 0 1 3}$ & $\mathbf{2 0 1 4}$ & $\mathbf{2 0 1 5}$ \\
\hline Proper Scale & 7066 & 8450 & 10072 & 11777 & 11453 & 15378 & 19444 & 20849 & 23879 \\
\hline $\begin{array}{c}\text { Foreign Exchange Reserves } \\
\begin{array}{c}\text { Extra Foreign Exchange } \\
\text { Reserves }\end{array}\end{array}$ & 15282 & 19460 & 23991 & 28473 & 31811 & 33115 & 38213 & 38430 & 33304 \\
\hline
\end{tabular}

The corresponding bar graph is shown below:

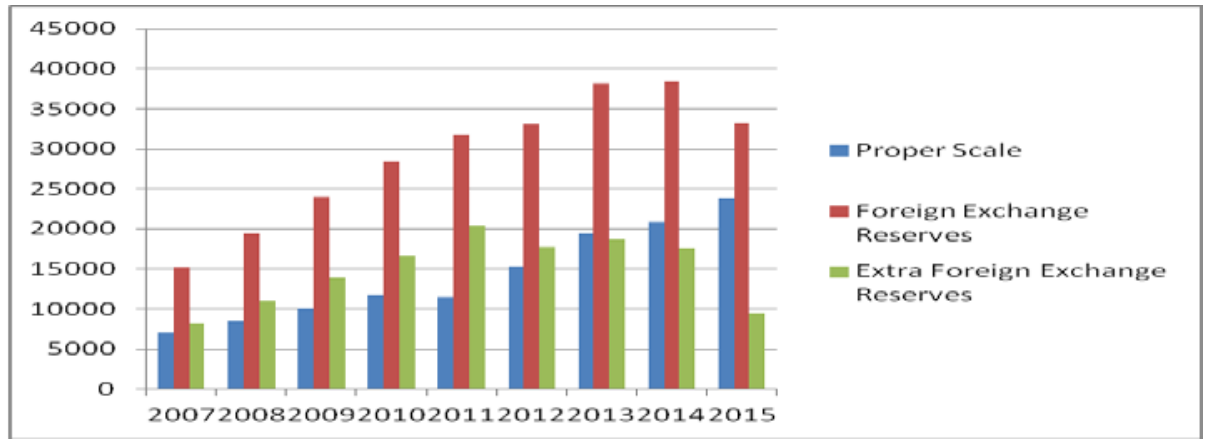

Fig. 1. The corresponding bar graph

It can be seen from the figure, China's foreign exchange reserves have decreased slightly since 2014, and China's excess foreign exchange reserve has decreased to some extent. This is mainly giving the credit to our foreign exchange measures which takes a very good effect.

\section{CONCLUSION}

The method of calculating foreign exchange reserves is from the the perspective of demand. Money means of purchase, means of payment and wealth functions determine a country's demand for foreign exchange reserves. After collecting all the data we calculate the Chinese proper scale of foreign exchange reserves. From the figures, we can see that Chinese foreign exchange reserves increased from 2007 to 2013 and decreased slightly from 2014. The excess foreign exchange reserves exist in China and the excess foreign exchange reserves show an upward trend year by year but in 2014 there is a turning point.

\section{REFERENCES}

[1] T. Robert, Gold and Dollar Crisis in the Future of Free Convertibility, the Commercial Press, 1997.

[2] E. Cheng, C. Wang, "The Possibility and Realization Path of the Creation of the World Currency”, Shanghai economics, 1st issue, 2013.

[3] X. Xu, "International Economy Theory", the Chinese Economy Press, 2003.

[4] N. Wu, "Research on China' Foreign Exchange Reserves" Chinese Finacial Press, 2014.

[5] J. Li, "the Proper Scale of China's Foreign Exchange Reserves", Chinese Economy Press, 2014. 